\title{
An Evaluation of Proposed Mechanisms of Slab Flattening in Central Mexico
}

\author{
Steven M. Skinner ${ }^{1}$ and Robert W. Clayton ${ }^{1}$
}

\begin{abstract}
Central Mexico is the site of an enigmatic zone of flat subduction. The general geometry of the subducting slab has been known for some time and is characterized by a horizontal zone bounded on either side by two moderately dipping sections. We systematically evaluate proposed hypotheses for shallow subduction in Mexico based on the spatial and temporal evidence, and we find no simple or obvious explanation for the shallow subduction in Mexico. We are unable to locate an oceanic lithosphere impactor, or the conjugate of an impactor, that is most often called upon to explain shallow subduction zones as in South America, Japan, and Laramide deformation in the US. The only bathymetric feature that is of the right age and in the correct position on the conjugate plate is a set of unnamed seamounts that are too small to have a significant effect on the buoyancy of the slab. The only candidate that we cannot dismiss is a change in the dynamics of subduction through a change in wedge viscosity, possibly caused by water brought in by the slab.
\end{abstract}

Key words: Mexico, flat slab, subduction.

\section{Introduction}

The major driving force of plate motion is slab buoyancy and the pull of subducting slabs descending into the mantle (BILLEN and HiRTH, 2007; CHAPPLE and Tullis, 1977; Forsyth and Uyeda, 1975). However, the current understanding of the initiation of subduction zones and the balance of forces controlling the $3 \mathrm{D}$ geometry and evolution of a subducting slab is not well understood (BILLEN, 2008). The angle of subduction influences the overall state of stress in the overriding slab, the resulting mode of deformation, and the location and type of arc volcanism.

1 Division of Geological and Planetary Sciences, California Institute of Technology, Pasadena, CA 91125, USA. E-mail: Skinner@caltech.edu
Shallow or flat subduction occurs in $10 \%$ of the subduction zones present today (VAN HUNEN et al., 2002). The global variation of slab dips is shown in Fig. 1. Present day zones of shallow subduction include the Nankai trough of Japan, northern and southern Peru, Central Chile, East Aleutians in Alaska, and Mexico. A number of these are coincident with oceanic impactors, anomalously thick crust in the form of an aseismic ridge or plateau, that are presumed to be the cause of the shallow geometry. The Chilean flat slab coincides with the subduction of the Juan-Fernandez ridge (ANDERson et al., 2007; Kay and Abbruzzi, 1996; Pilger, 1981). The Peruvian flat slab is a combination of two adjacent flat segments resulting from subduction of the Nazca ridge and the Inca plateau (GuTSCHER et al., 1999b). There is a possible flat slab segment in Ecuador that correlates with the subduction of the Carnegie ridge (Gutscher et al., 1999a). Oceanic lithosphere of the Caribbean oceanic plateau might be causing a flat slab in northwestern Columbia (GuTscher et al., 2000a). Subduction of the Cocos ridge has led to a flat slab in Costa Rica (РRотti et al., 1995; SAK et al., 2009), and the Yakutat terrane is subducting in the zone of the East Aleutian flat slab (BRocher et al., 1994; FuIs et al., 2008). The flat slab of southwestern Japan has been linked to subduction of the Izu Bonin arc and the Palau-Kyushu ridge (Gutscher et al., 2000b), and western New Guinea has a flat segment linked to subduction of the Euripik ridge (GuTsCHER et al., 2000b). In northern Chile, the current dip of the slab is not flat but is actively flattening due to the subduction of the Iquique ridge (EsPURT et al., 2008).

However, in two cases there is no obvious impactor associated with the flat subduction. In the Cascadia subduction zone, for example, there is no evidence for thickened crust subducting along the 


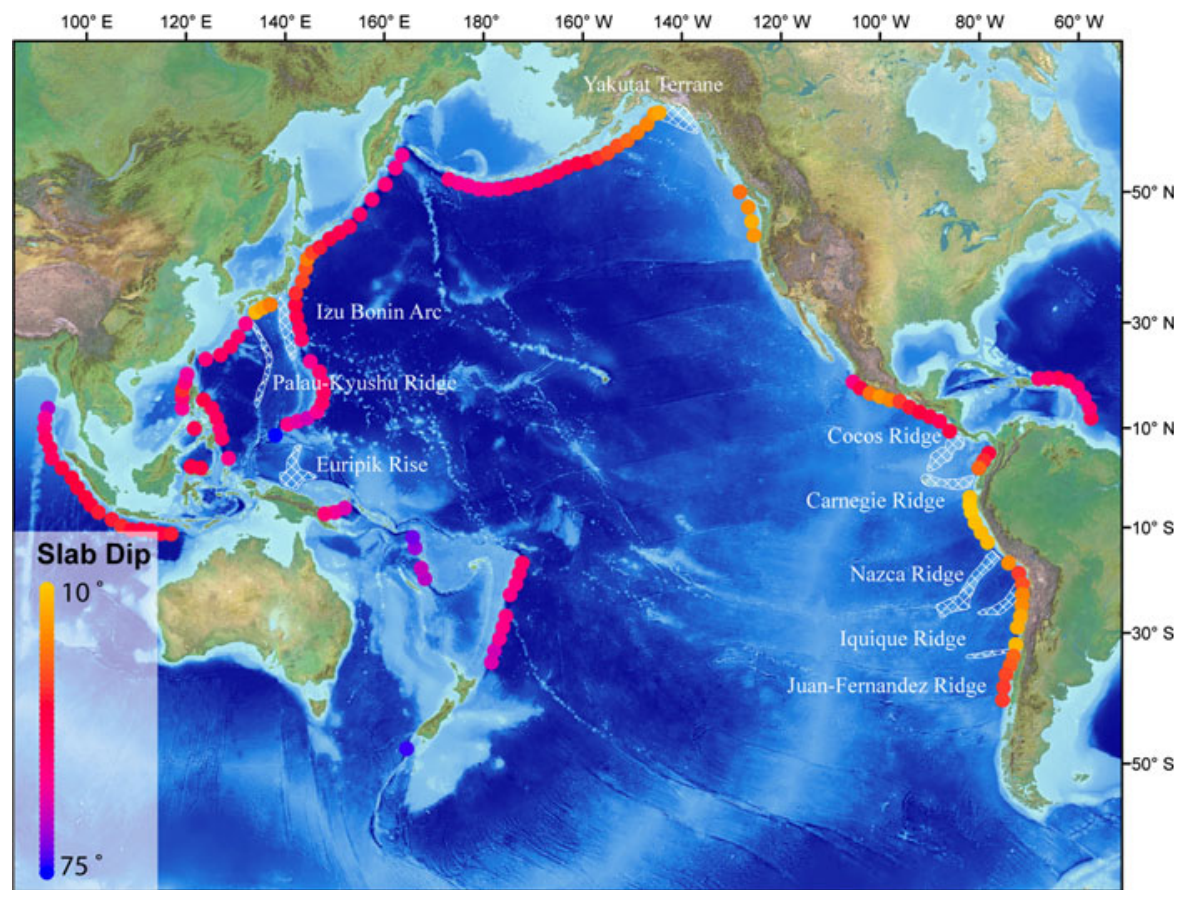

Figure 1

Map of the Pacific seafloor showing the dip of the shallow ( $<125 \mathrm{~km}$ depth) portion of subducting slabs (LALLEMAND et al., 2005), and subducting bathymetric highs that have been correlated with zones of shallow subduction (white crosshatched pattern)

shallow dipping Washington segment (GUTSCHER et al., 2000c). The flat slab in Mexico has been attributed to the Tehuantepec ridge (GUTSCHER et al., 2000c); however, the Tehuantepec ridge is being subducted at a point where the slab is dipping at $30^{\circ}$ and appears to have little effect on the angle. In locations where an impactor has been identified, the spatial correlation between the impactor and zone of shallow subduction does not hold up when looked at in detail. In the Nankai trough, for example, the Palau-Kyushu ridge is entering the trench at the southern limit of the shallow zone. Figure 2 shows the anticorrelation between the shallow zone and where ridges are subducting. The fact that the impactor and zone of shallow subduction do not align suggests that it is not the buoyancy of the ridge itself that is holding up the slab, but a dynamic process that continues to operate in the wake trailing the impacting ridge.

As shown in Fig. 3, there are also cases where apparent buoyant impactors have little to no effect on the geometry of the subducting slab. The Emperor seamounts are subducting at the Kurile trench; the
Ogasawara plateau, Magellan seamounts, and Caroline ridge are all subducting at the Mariana trench; the Ozbourn-Louisville seamounts are subducting at the Kermadec trench; and the Chile rise is subducting at the Peru-Chile trench. These are just a sample of the largest thickness anomalies that are subducting without shallowing the dip of the downgoing slab.

\section{Current State of Subduction in Central Mexico}

The central Mexico subduction zone is of particular interest because it does not have an impacting ridge yet is one of the shallowest slabs that has been measured. Understanding the flat slab in Mexico is key to reevaluating the proposed mechanisms for shallow slabs around the globe. Along the western Mexico margin, the Cocos plate is subducting under the North America plate at a rate varying between 4.7 and $6.8 \mathrm{~cm}$ /year (DEMETs et al., 1994). As shown in Fig. 4, the subducted slab is shown by receiver function analysis to transition from a normal dip at 


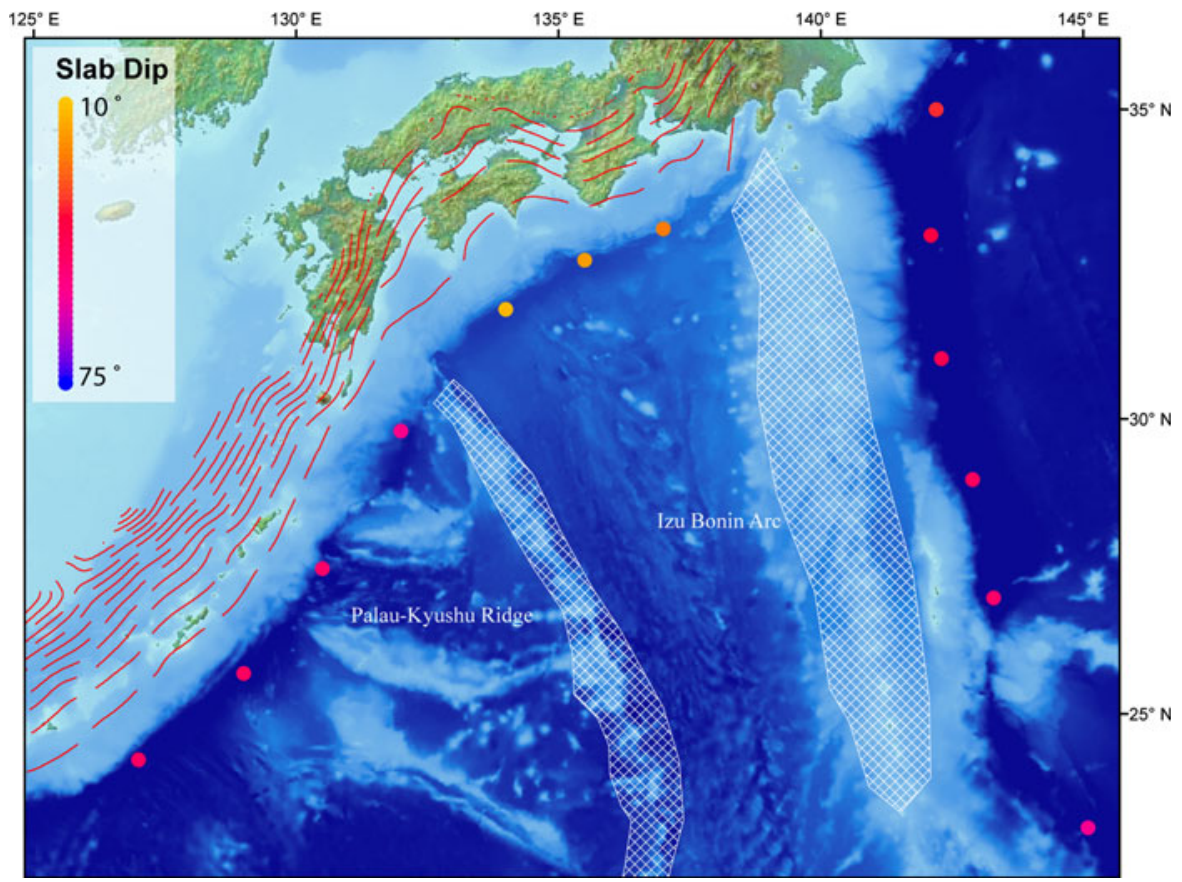

Figure 2

Detail view of the shallow slab segment of Japan. Dashed red lines are $20 \mathrm{~km}$ contour lines of slab depth from model of HAYEs et al. (2009). Colored dots are slab dip from LALLEMAND et al. (2005). The shallow segment appears to correlate with the subduction of the Shikoku basin rather than the two ridges that flank it

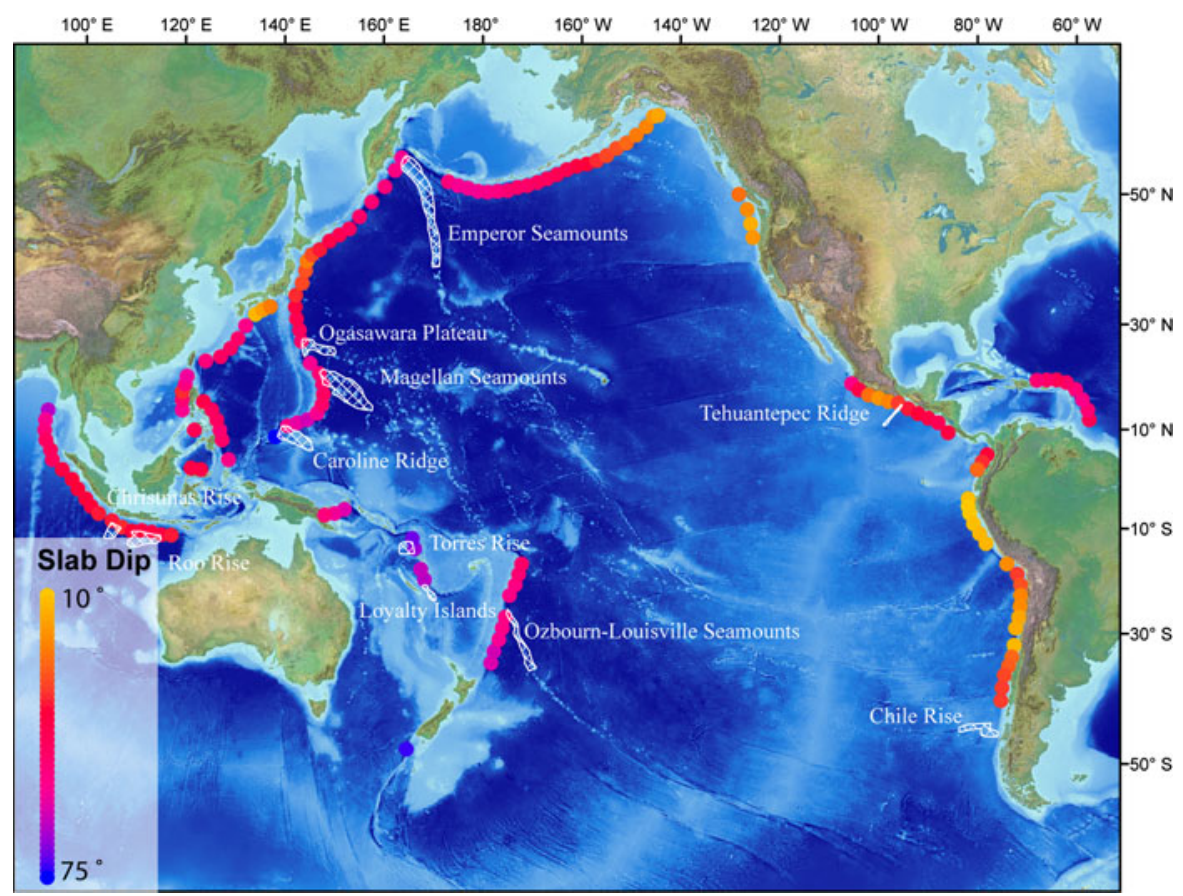

Figure 3

Map of the Pacific seafloor with labeled lithosphere anomalies (white crosshatched regions) that are subducting with no apparent effect on slab dip. Colored dots are slab dip from LaLLEMAND et al. (2005) 


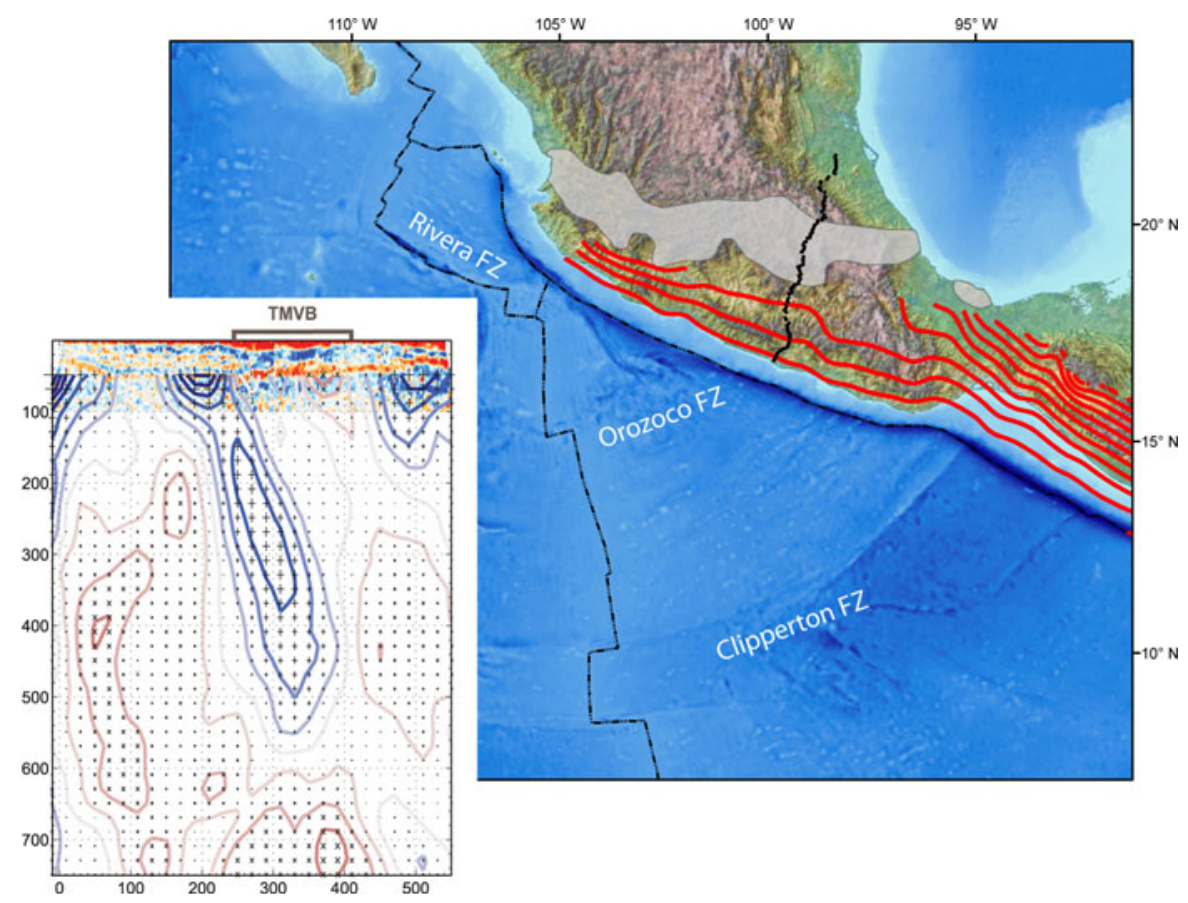

Figure 4

Combined receiver function and tomographic image from the Meso American Subduction Experiment (MASE) transect modified from PÉREZCAMpos et al. (2008). Vertical axis is kilometers below sea level, horzontal axis is distance along the MASE transect. The location map of Mexico shows the relative location of the MASE transect (black dots) to the trans-Mexican Volcanic Belt (TMVB) (gray area), offshore bathymetric features, and the dip of the subducted Cocos plate in $20 \mathrm{~km}$ contours (HAYEs et al., 2009). Plate boundaries from BIRD (2003)

the trench to sub-horizontal at $80 \mathrm{~km}$ from the trench (Kim et al., 2010; PARdo and SuÁrez, 1995; PérezCAmpos et al., 2008; SuÁrez et al., 1999). The horizontal slab persists to $250 \mathrm{~km}$ from the trench where it descends into the mantle with a $75^{\circ}$ dip and is recognizable in tomographic images to a depth of $500 \mathrm{~km}$ (Husker and Davis, 2009; KIM et al., 2010; PÉREZ-CAMpos et al., 2008). An ultra low velocity layer, approximately $3 \mathrm{~km}$ thick is imaged on top of the slab from the trench through the horizontal section. The overriding plate appears to be in an overall state of extension rather than compression (SINGH and PARDO, 1993), which is counterintuitive when considering the compressive forces associated with the subduction collision and the traction of an underplated slab (De Franco et al., 2007; KePPIE, 2009; Moran-Zenteno et al., 2007; Nieto-SAmAniego et al., 2006).

The trans-Mexican Volcanic Belt has embayments along the landward projection of the Rivera, Orozoco, and Clipperton fracture zones suggesting that the Cocos plate is being further divided into smaller plates by tearing of the slab (BLATTER et al., 2007; Menard, 1978). The breakup of the Cocos plate allows the smaller fragments to rollback faster and results in the along trench dip variation (BILLEN, 2008).

\section{History of Subduction in Mexico}

The western Mexican margin has been a subduction margin for the past 160 million years (KEPPIE, 2004; Solari et al., 2007). The Sierra Madre Occidental, the subduction-related arc of western Mexico, initiated in the Jurassic and contains a continuous record of subduction-related magmatism from the Cretaceous and throughout the Cenozoic. The area has undergone moderate compressional deformation that correlates in time with Laramide deformation further north. Extension began in the early Eocene and continued through the Oligocene. Associated with the extension, is an ignimbrite flare-up that signals slab rollback or detachment of the slab 
(FERRARI et al., 2007). All of this early extension occurred while the margin was still under the compressive forces of subduction.

The details of the assembly of southwestern Mexico are complicated, but there are some aspects that can constrain the evolution of the slab geometry. The extent and migration of Cenozoic volcanism is related to the location of the subducted slab. Age data from the North American Volcanic Database (NAVDAT) and Moran-Zenteno et al., (2007) are plotted in Fig. 5 against distance from the paleotrench to show the space and time evolution of subduction related magmatic activity. At $20 \mathrm{Ma}$ the locus of subduction magmatism jumps $200 \mathrm{~km}$ inland from the trench. At $10 \mathrm{Ma}$ a rollback phase starts as the volcanism migrates toward the trench.

The migration of the arc needs to be viewed in relation to the reorganization of the oceanic plates offshore, namely the ridge jumps at 25, 12.5-11, and 6.5-3.5 Ma (Klitgord and Mammerickx, 1982; MAMmerickX and Klitgord, 1982; Moran-Zenteno et al., 2007). The southern Mexican margin has undergone a major reshaping in Tertiary time

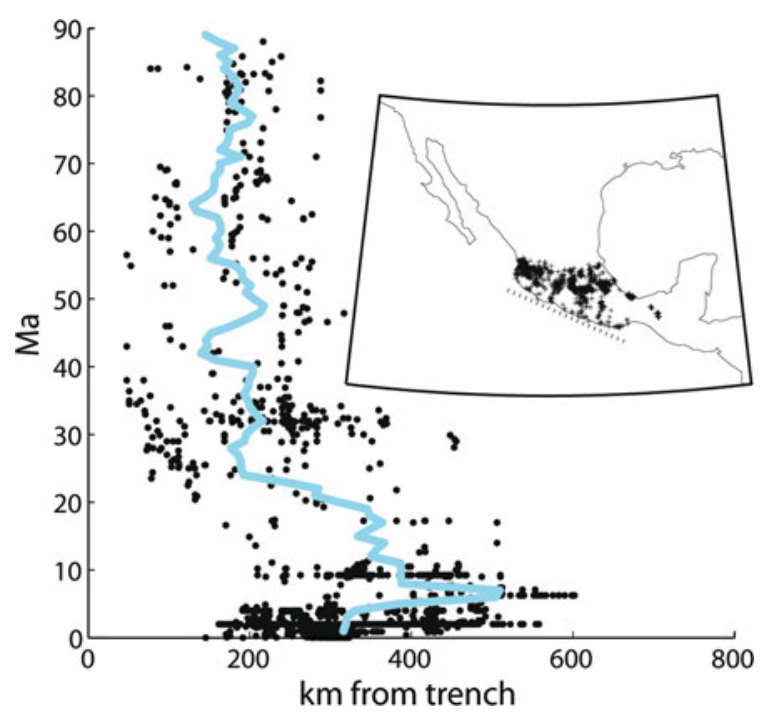

Figure 5

Distance of arc magmatism from the trench through time. The blue line is an 0.2 million-year moving average of the distance from the trench. There is a distinct change in the location of the arc starting at $25 \mathrm{Ma}$ that shows the location of active volcanism migrating northward away from the trench, then starts a rollback to the south. The inset map shows the extent of the data used (crosses) and the dotted line approximating the trench. Data are from the North American Volcanic Database and Moran-Zenteno et al., (2007)
(Moran-Zenteno et al., 1996). The truncation of structural trends in addition to the juxtaposition of the modern trench and the Paleogene batholith suggests subsequent forearc removal (KARIG, 1978; MORANZenteno et al., 2007, 1996; SchaAf et al., 1995). The Chortis block is often assumed to be the missing forearc, though this correlation is just as often called into question (Keppie and Moran-Zenteno, 2005; Moran-Zenteno et al., 2009; Ortega-Gutierrez et al., 2007; ORTEGa-ObREGON et al., 2008). Recent studies evaluating the multiple reconstructions proposed for the Chortis block do not find much evidence to support the hypothesis that it represents the missing forearc and prefer a model of wholesale subduction erosion (KePPIE, 2009).

\section{Proposed Causes of Zones of Shallow Subduction}

There are several factors that affect the geometry of subduction zones. A rapid convergence rate, trench-ward absolute motion of the upper plate, subduction of thickened oceanic crust, and young oceanic lithosphere are four factors that lead to shallowing of subducting plates (Cross and Pilger, 1982). These factors are discussed specifically for Mexico.

\subsection{Tehuantepec Ridge}

The southern Mexico subduction zone, near the Isthmus of Tehuantepec, exhibits all of the four factors that would lead to a shallow slab geometry as described by Cross and PILger (1982): the convergence rate of the Cocos and North American plates is rapid (approximately $6 \mathrm{~cm} /$ year); the North American plate is overriding the Cocos plate in an absolute motion reference frame; the Tehuantepec ridge is currently being subducted; and the subducting lithosphere has been younger than $10 \mathrm{Ma}$ for the past $40 \mathrm{Ma}$ (Cross and Pilger, 1982; Müller et al., 2008). These factors predict that the subducted Cocos plate in this region should have a very shallow dip, but it actually has a moderate dip of $30^{\circ}$.

One of the most obvious positive seafloor anomalies on the Cocos plate is the Tehuantepec ridge. The ridge is a compression structure that stretches for 


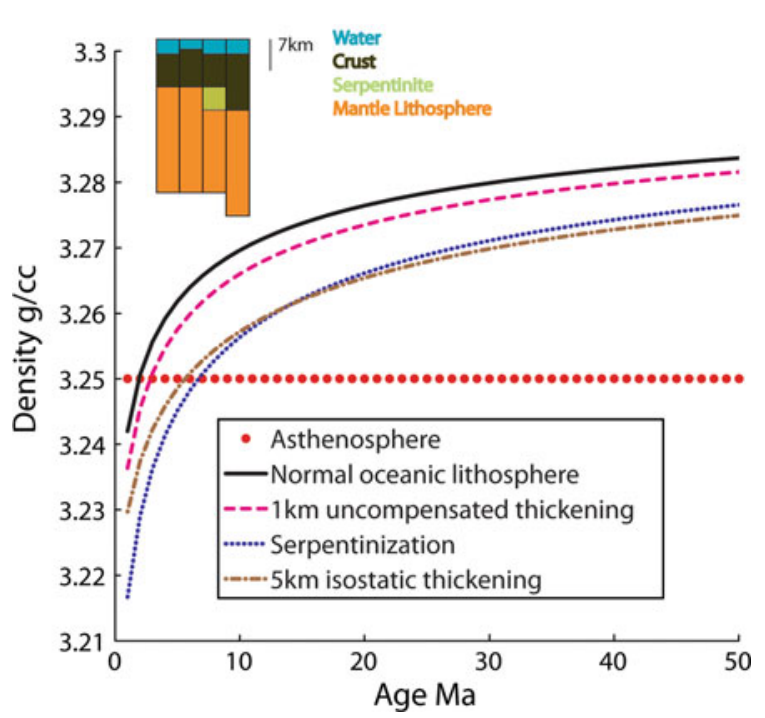

Figure 6

Average buoyancy at a given age of the crustal columns for four possible types of oceanic lithosphere subducted under Mexico, calculated using half space cooling model (Turcotte and SchuBERT, 2002). Red dotted line is the density of asthenosphere for reference. The modeled lithosphere will resist subduction until it crosses above the asthenosphere line. The $5 \mathrm{Ma}$ time slice of the four models of oceanic lithosphere used in calculating the density variation with age are shown. The models include unaltered normal oceanic lithosphere, $1 \mathrm{~km}$ of uncompensated thickening to represent the Tehuantepec ridge, $15 \%$ serpentinization if the upper $5 \mathrm{~km}$ of the oceanic mantle lithosphere, and a $5 \mathrm{~km}$ isostatic compensated thickening of the oceanic crust to represent seamounts formed on a spreading ridge

more than $200 \mathrm{~km}$ along the Clipperton fracture zone. The ridge marks the boundary of oceanic lithosphere that is, on average, 7 million years younger and $800 \mathrm{~m}$ shallower to the north (MANEA et al., 2005). The ridge itself has a maximum relief of roughly $1 \mathrm{~km}$ relative to the seafloor to the north and is, on average, $10 \mathrm{~km}$ wide. Assuming the Tehuantepec ridge is simply a kilometer increase in oceanic crust, the resultant buoyancy increase is only $0.12 \%$ (see Fig. 6). The Tehuantepec ridge is thought to have formed as a transform fault on the Guadalupe plate at $15-20 \mathrm{Ma}$; in addition, it is currently encountering the trench at the transition zone of shallow to steep subduction and has no historic or kinematic link to the current zone of flat subduction (Manea et al., 2005). The Tehuantepec ridge has a trend perpendicular to the trench which reduces the effect of any positive buoyancy (Martinod et al., 2005). The Tehuantepec ridge impacts in the wrong place
(500 km to the southeast of the zone of flat subduction) and has no history of lateral movement along the trench (MANEA et al., 2005).

\subsection{Seamounts}

There is a seamount chain (the Moonless Mountains) on the Pacific plate between the Murray and Clarion fracture zones that may have had a correlative chain, the Chumbia seamount ridge, on the now subducted Farallon plate (KePpIE and Moran-Zenteno, 2005). The seamounts in this chain do not have flexural or gravity moats around them, indicating that they were formed on or very near the spreading ridge (W RIBE, 1984). The lithosphere that surrounds the Moonless Mountains is roughly 40 million years old (MüLLER et al., 2008). When the Cocos plate started to shallow 30 million years ago, as evidenced by migration of volcanism, the lithosphere at the trench was 10 million years old (MüLLER et al., 2008) and would be neutrally buoyant. If a corollary to the Moonless Mountains did exist on the Cocos plate, it is of the right age to contribute to the flattening of the slab; however, reconstructions based on the rotation poles and the error analysis of Doubrovine and TARDUnO (2008) (see Fig. 7) show that the Moonless Mountains mirror image would intersect the Mexican margin further to the north than the extent of the zone of shallow subduction, and, hence, is not likely the cause.

By using the stage rotations of Doubrovine and TARDUno (2008), a conjugate to the current Mexican margin can be rotated to indicate the area of the Pacific plate that corresponds to the area on the Farallon plate that subducted at $30 \mathrm{Ma}$ when the slab shallowed. As shown in Fig. 8, this rotation reveals a set of small unnamed seamounts that would have intersected the margin around the latitude of Acapulco and can be correlated in space and time to the flat segment of the slab. The buoyancy of these seamounts alone is insufficient to cause a flat slab (Cloos, 1993). We can use a simplified geometry to estimate the volumetric differences and resulting changes in buoyancy due to various forms of thickened oceanic lithosphere. From global bathymetry data we extract a representative width and height of the given bathymetric anomaly, then calculate the volume assuming a conical shape for a seamount or a 

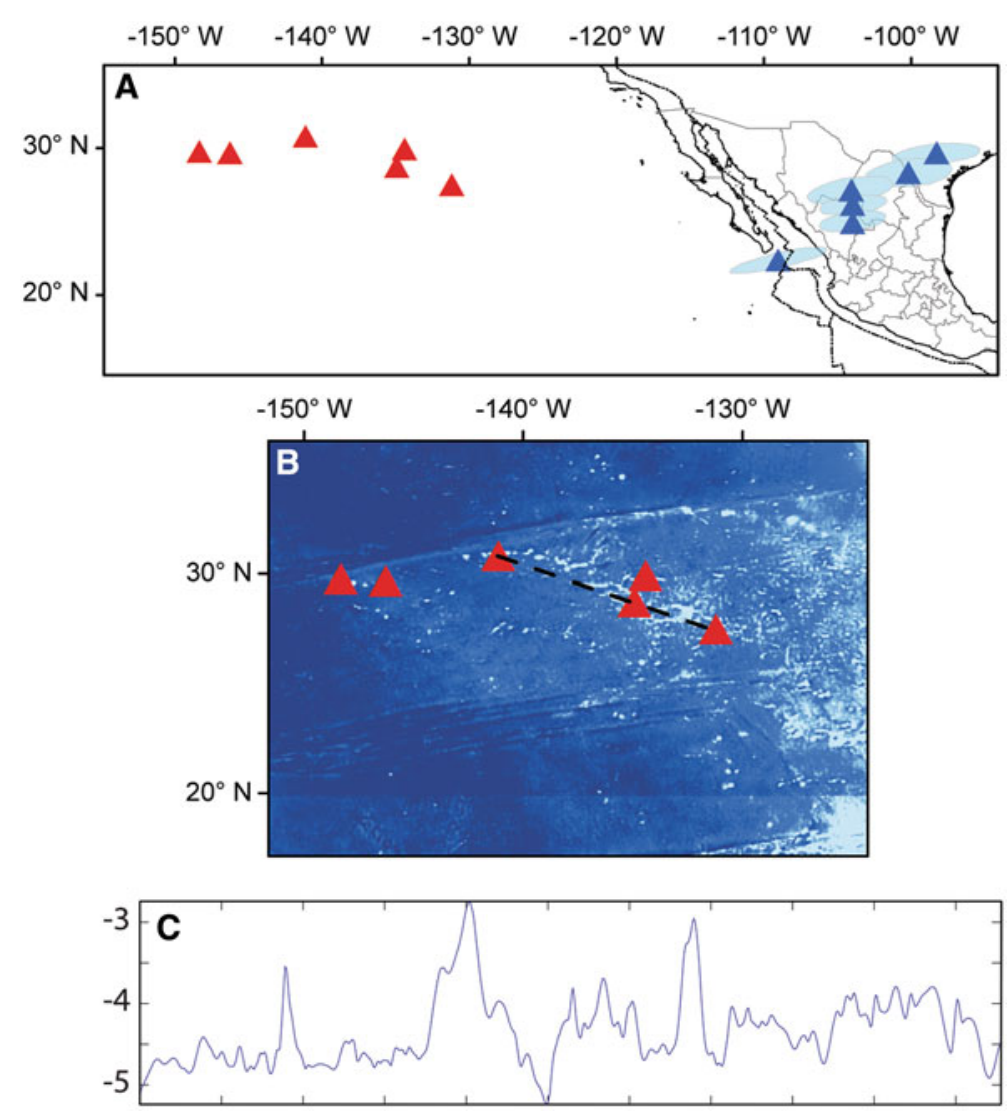

Figure 7

A tectonic reconstruction of the Moonless Mountains at 30 Ma. a Depicts the current location of the Moonless Mountains as red triangles. Blue triangles show the reconstructed location relative to North America of the hypothetical correlative chain of seamounts on the Farallon plate at $30 \mathrm{Ma}$ in a fixed North America reference frame. Light blue areas are the error ellipses of the rotations given by DouBRovine and TARDUNO (2008). b Shows the bathymetry of the area around the moonless mountains and the location of the representative bathymetric profile shown to the right. $\mathbf{c}$ Is a representative profile along the dashed line in (b). Vertical axis is kilometers below sea level, vertical exaggeration is 100 times

triangular prism for an aseismic ridge. The estimated increase in crustal volume is then normalized by the aerial extent of the feature in order to compare thickening per unit area. Using this method the unnamed mountains are approximately $10 \%$ of the crustal volume increase associated with the Nazca or Juan Fernandez ridge.

\subsection{Age of the Subducting Plate}

One of the predictions of plate tectonics is that the angle of subduction is a function of the age of the subducting plate, because as a plate ages it cools and increases in density (BILLEN and HiRTH, 2007; PARsons and Sclater, 1977). The relationship between age and density is clearly seen in the half space cooling models of Fig. 6. However, when the angle of subduction and the age of actual subduction zones are analyzed, the correlation is quite weak (CRUCIANI et al., 2005; JARRARD, 1986). This is evident in the case of central Mexico, where the Cocos plate exhibits steep subduction in the north where the subducting oceanic lithosphere is younger than the lithosphere of the flat segment to the south (Müller et al., 2008; PARdo and SuÁrez, 1993, 1995) (see Fig. 4).

It is possible for an ephemeral spreading center to have existed between the Farallon and an unknown microplate. If this failed ridge was near the trench it could produce very young and buoyant lithosphere that would decrease the angle of subduction. This hypothetical ridge would be entirely contained within 

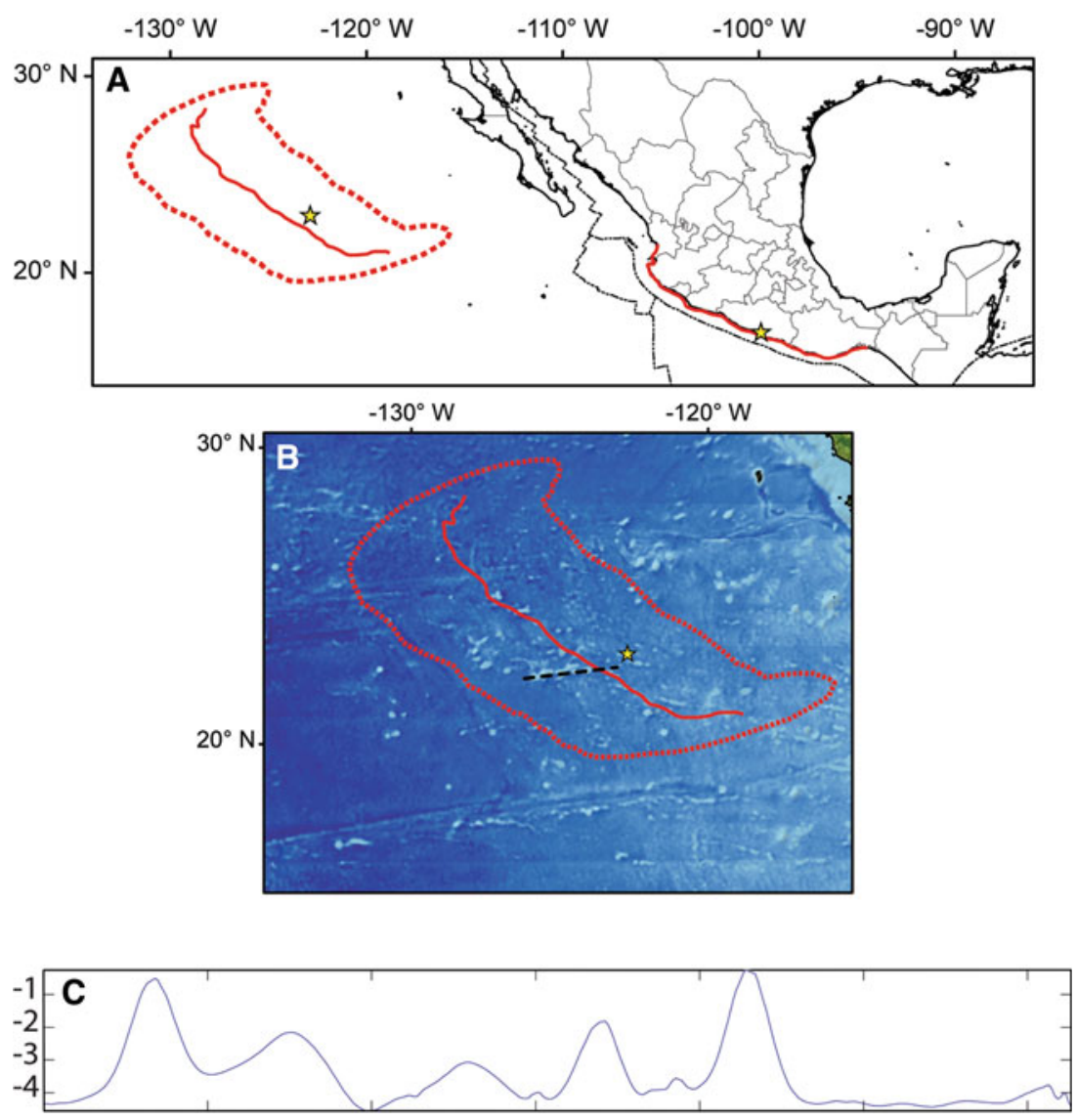

Figure 8

a Shows the Mexican coastline transformed by the rotations of Doubrovine and TARduno (2008) to show the area of the Pacific plate that is the corollary to the oceanic lithosphere that was subducting along the southern Mexican margin at $30 \mathrm{Ma}$. The yellow stars are the current and rotated location of Acapulco for reference. There is a small chain of seamounts near what would have been the latitude of Acapulco. The dashed red line is the total $95 \%$ confidence area of the error ellipses associated with the rotated points of the coast (solid red line). b Shows the bathymetry of the area around the unnamed seamounts and the location of the representative bathymetric profile. $\mathbf{c}$ Is a representative profile along the dashed line in (b). Vertical axis is kilometers below sea level, vertical exaggeration is 100 times

subducted Farallon plate, and the evidence for it completely subducted. Although the tectonic plates in the area underwent frequent reorganization around the time of the slab shallowing, there is no evidence for such a spreading ridge in the geologic or geochemical record of the upper plate.

\subsection{Hydrothermal Alteration}

Age alone may not be the sole cause for the angle of the Cocos slab, but could be a major component. The seafloor on both sides of the spreading ridge in the zone of flat subduction is extremely rough. The area is the site of numerous fracture zones and failed rifting events. One of the mapped failed rifts on the
Pacific plate was dredged as part of the Ocean Drilling Project and the recovered sample contained serpentinite (LONSDALE, 2005). The alteration or serpentinization of the oceanic lithosphere causes a decrease in the average density of the lithosphere and could increase the buoyancy of the slab, causing it to go flat. Hydrothermal alteration will likely increase with increased fracturing, although we have no way of knowing the fracture density of the plate that subducted at $20 \mathrm{Ma}$ given the fact that fracture causing events such as ridge jumps and forearc bulges are not necessarily recorded symmetrically about the new spreading center. The bending of the Cocos plate preferentially induces the reactivation of faults and fractures, creating a horst and graben structure 
(Aubouin et al., 1982; Grevemeyer et al., 2005; RufF, 1989). The faulting of the lithosphere allows water to penetrate into the young warm slab and alter the density. This is a process that occurs at all subduction zones; however, due to the consistently young lithosphere subducting in this area, the higher temperature of the slab will increase hydrothermal alteration independent of the degree of fracturing. Altering the top $5 \mathrm{~km}$ of the mantle lithosphere by $15 \%$ serpentinization doubles the length of time for which a slab is neutrally buoyant (see Fig. 6). Recent geophysical studies in Mexico have determined that there is a hydrous layer at the plate interface (KIM et al., 2010). Remobilization of fluids entrained with the downgoing slab by serpentinization may be the source of these hydrous phases.

\subsection{Slab Detachment and Flexure}

Tomographic images reveal the foundering segments of the Farallon slab beneath North America. The tomographic model of Gorbatov and FukaO (2005) reveals a southward propagating tear in the slab at $600 \mathrm{~km}$ depth that is a result of the differential motion between the Cocos and subducted Farallon plates. They speculate that the tear and differential rotation buckles the Cocos plate and caused uplift of the slab in the region of the TMVB, producing the flat slab geometry. There are also large discrepancies between tomographic models of the region. The more detailed tomographic model of Husker and DAvis (2009) places the truncated edge of the slab roughly $500 \mathrm{~km}$ to the south of where Gorbatov and Fukao locate it, which makes the uplift mechanism less likely. Other tomographic models locate a shallower gap in the slab under northern Central America (Rogers et al., 2002), and it is not clear how truncation of the slab at a depth of $300 \mathrm{~km}$ beneath Guatemala, Honduras, and Nicaragua would relate to the model of Gorbatov and Fukao.

\subsection{Chortis Block}

The origin and location of the Chortis block (present day Nicaragua) through time is highly debated. One reconstruction places the Chortis block along the Acapulco trench at 50 Ma (PIndell et al.,
1988; Ross and Scotese, 1988). The block then migrates to the east with the Farallon-North AmericaCaribbean triple junction, which changes the margin from a North American-Caribbean to North American-Farallon plate boundary (MorAn-ZENTENo et al., 1996). The change in the plate pair exposes the southern Mexican margin to the faster Farallon-North America convergence rate, which may lead to the flattening of the slab, though it is unclear why the margin to the north with the same convergence rate would not also be flat. Other studies (KePPIE, 2009; Keppie and Moran-Zenteno, 2005) propose models for the evolution of the Chortis block that make it unrelated to the flat slab in central Mexico. It is unlikely that the Chortis block is the cause of the flat slab, yet the knowledge of its location through time is needed for a complete model of the area.

\subsection{Continental Root}

Slab suction is an important force influencing the geometry at subduction zones. Viscously driven flow of the asthenosphere by the downgoing slab creates a zone of negative pressure in the mantle wedge (Tovish et al., 1978). The suction force alone may not provide enough lift to drive slabs flat, but may prove more effective when combined with excessively buoyant lithosphere in the form of an oceanic plateau (VAN HUNEN et al., 2004). The suction force in the mantle wedge can be greatly increased by a continental root that penetrates the asthenosphere (O'DrisCOLl et al., 2009). The crustal root blocks flow perpendicular to the trench resulting in a higher negative pressure in the space between the trench and the root that can assist in pulling up the slab. This mechanism is proposed as a contributing factor for the Laramide, and has been suggested for central Mexico because the elevated TMVB may indicate the presence of the a crustal root (Urrutia-Fucugauchi and Flores-Ruiz, 1996). However, as shown in Pérez-CAmpos et al. (2008), the crust under the TMVB is only $45 \mathrm{~km}$ thick and, hence, there is no deep crustal root.

\subsection{Hydration of the Mantle Wedge}

The viscosity of the mantle wedge can be decreased by the addition of fluids released from 
the slab; this low viscosity wedge or channel can change the dip of the downgoing slab and has been modeled to create flat lying slabs as observed in Mexico (Manea and Gurnis, 2007). There is some evidence in the attenuation study of CHEN and Clayton (2009) that zones of low Q in the mantle wedge may be due to fluids from the slab. Geochemical studies of the TMVB show that the sub-arc mantle is highly heterogeneous and have found locations with a magmatic water content in excess of $8 \mathrm{wt} \%$ (BLATTER and CARMichael, 1998; JoHNSON et al., 2009). We know that excess hydration can cause a slab to flatten; however, the cause of excess water in the Mexican subduction zone has yet to be explained. Tectonic erosion is one way to subduct large amounts of water laden sediments (DominguEZ et al., 2000). In Mexico there is evidence for extreme tectonic erosion, namely, the entire Oligocene forearc is missing and the associated batholith is sitting adjacent to the modern trench (KePPIE et al., 2009a, b; Moran-Zenteno et al., 2007). The juxtaposition of the Oligocene arc with the modern trench and the truncation of other structural features reveals how much of the Mexican margin has been lost to tectonic erosion.

Seamounts may not have enough positive buoyancy to flatten the slab, but they do create a long lived period of subducting extreme relief that could lead to a prolonged period of subduction erosion (vON HUENE and Scholl, 1991). The subduction on individual seamounts has been shown, through analog models, to cause erosion of the overriding plate (Dominguez et al., 1998, 2000). The unnamed mountains range in age from roughly $35-25 \mathrm{Ma}$ and stretch across $500 \mathrm{~km}$ (see Fig. 8). The convergence rate along the Middle America Trench varies widely though averaging in space and time the margin would be continually impacted for a span of $6 \mathrm{Ma}$ assuming a perfect mirroring of the unnamed mountains (DouBROVINE and TARDUnO, 2008; Müller et al., 2008). The erosion of the margin corresponds with a 29-19 Ma gap in arc magmatism (KePPIE et al., 2009b). Recent numerical modeling has shown the rapid removal of large blocks of continental forearc as one possible mode of subduction erosion that shaped the Mexican margin (KePPIE et al., 2009a).
The eroded forearc would be highly fractured in this catastrophic event leading to an increase in pore space for fluids to be entrained with the downgoing plate. Modeling indicates that the eroded material could be underplated or transported deep into the mantle (KePPIE et al., 2009a). The low viscosity channel that forms from the subducted material and fluid would also decouple the upper and lower plates and cause the lack of compression that we see in Mexico.

\section{Discussion}

Looking for a single cause of flat slab subduction reveals the complexity and multifaceted nature of subduction zone dynamics. Single trench correlations quickly break down when extended to the global scale. The often called upon correlation between the location of flat slabs and the presence of a subducting aseismic ridge or plateau is quite strong; however, this does not imply direct causation. Most flat slabs have an associated subducting ridge, but not all subducting ridges produce flat slabs. The fact that the correlation between ridges and shallow zones is not one-to-one means that it is not likely the sole cause of flat subduction. We have shown that, by adding a second variable, in this case age, we are able to explain some of the zones where a ridge is subducting yet fails to produce a shallow slab segment (see Fig. 9). This is just one example of the need for a comprehensive evaluation of the parameters that influence the dip of subducting plates. One proposed cause of the Laramide flat slab is the subduction of a conjugate oceanic plateau to the Shatsky Rise; though, as we have shown, subduction of thickened oceanic lithosphere is neither a sufficient or necessary condition for shallow subduction. We find hydration of the mantle wedge to be the only mechanism that there is no evidence against causing the flat slab in Mexico. Further study of the fluid budget of the downgoing slab and the change in mantle viscosity with the addition of fluids is needed to evaluate hydration as the cause of the Mexican flat slab and possibly the key mechanism for shallow slabs worldwide. 


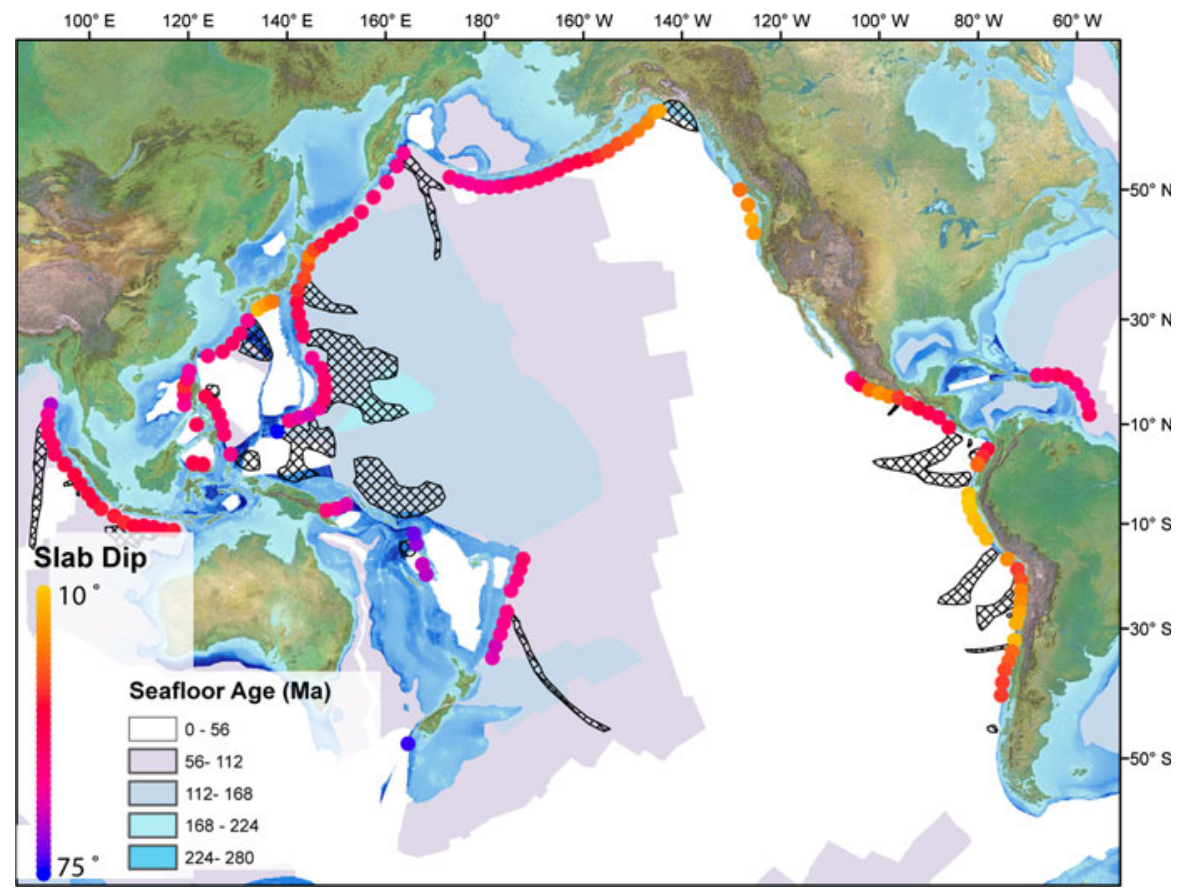

Figure 9

Map of the Pacific seafloor age (MüLLER et al., 2008), shallow slab segment dips (LALLEMAND et al., 2005), and subducting bathymetric highs (crosshatched pattern). Not all bathymetric highs are correlated with a zone of shallow subduction. Although there is no direct correlation between the age of the subducting lithosphere and the dip of the slab, there appears to be a maximum plate age past which the slab cannot support a flat segment. This explains the subduction of ridges that do not form a shallow slab in the western Pacific

\section{Conclusions}

Subducting buoyant ridges, seamounts, and plateaus do not directly cause flat slabs but are, rather, a catalyst of other dynamic mantle processes. Determining the combination of forces that lead to flat slabs is important not only for our understanding of the current zones of flat subduction but also the geologic history of western North America and inferred periods of flat subduction. The geometry that we see in the present day Mexican flat slab appears to be the result of the dynamic response of subduction to hydration of the mantle wedge that occurred 30 million years ago. The direct evidence for the flattening mechanism has long been destroyed, and there is no suitable impactor on the conjugate plate. Hydration of the mantle wedge is the only feasible mechanism to change the slab geometry in Mexico, although the process is not completely understood. The cause of the intense subduction erosion that leads to the hydration has yet to be identified, yet appears to be the only viable explanation for the geometry of both the slab and the margin.

\section{Acknowledgments}

This study was supported by the Gordon and Betty Moore Foundation through the Tectonics Observatory at Caltech. This is contribution number 136 from the Caltech Tectonics Observatory.

Open Access This article is distributed under the terms of the Creative Commons Attribution Noncommercial License which permits any noncommercial use, distribution, and reproduction in any medium, provided the original author(s) and source are credited.

\section{REFERENCES}

Anderson, M., Alvarado, P., Zandt, G. and Beck, S. (2007), Geometry and Brittle Deformation of the Subducting Nazca Plate, Central Chile and Argentina, Geophysical Journal International 171, 419-434. 
Auboun, J., Stephan, J.F., Roump, J. and Renard, V. (1982), The Middle America Trench as an Example of a Subduction Zone, Tectonophysics 86, 113-132.

Billen, M.I. (2008), Modeling the Dynamics of Subducting Slabs, Annual Review of Earth and Planetary Sciences 36, 325-356.

Billen, M.I. and Hirth, G. (2007), Rheologic Controls on Slab Dynamics, Geochemistry Geophysics Geosystems 8, Q08012, doi:10.1029/2007gc001597.

BiRD, P. (2003), An Updated Digital Model of Plate Boundaries, Geochemistry Geophysics Geosystems 4, 1027, doi:10.1029/ $2001 \mathrm{gc000252.}$

Blatter, D.L. and Carmichael, I.S.E. (1998), Hornblende Peridotite Xenoliths from Central Mexico Reveal the Highly Oxidized Nature of Subarc Upper Mantle, Geology 26, 1035-1038.

Blatter, D.L., Farmer, G.L. and Carmichael, I.S.E. (2007), A North-South Transect across the Central Mexican Volcanic Belt at Similar to 100 Degrees W: Spatial Distribution, Petrological, Geochemical, and Isotopic Characteristics of Quaternary Volcanism, Journal of Petrology 48, 901-950.

Brocher, T.M., Fuis, G.S., Fisher, M.A., Plafker, G., Moses, M.J., TABer, J.J. and Christensen, N.I. (1994), Mapping the Megathrust beneath the Northern Gulf of Alaska Using Wide-Angle Seismic Data, Journal of geophysical research 99, 11663-11685.

Chapple, W.M. and Tullis, T.E. (1977), Evaluation of Forces That Drive Plates, Journal of geophysical research 82, 1967-1984.

Chen, T. and Clayton, R.W. (2009), Seismic Attenuation Structure in Central Mexico: Image of a Focused High-Attenuation Zone in the Mantle Wedge, Journal of geophysical research 114, B07304, doi:10.1029/2008jb005964.

Cloos, M. (1993), Lithospheric Buoyancy and Collisional Orogenesis; Subduction of Oceanic Plateaus, Continental Margins, Island Arcs, Spreading Ridges, and Seamounts, Geological Society of America Bulletin 105, 715-737.

Cross, T.A. and Pilger, R.H. (1982), Controls of Subduction Geometry, Location of Magmatic Arcs, and Tectonics of Arc and Back-Arc Regions, Geological Society of America Bulletin 93, 545-562.

Cruciani, C., Carminati, E. and Doglioni, C. (2005), Slab Dip Vs. Lithosphere Age: No Direct Function, Earth and Planetary Science Letters 238, 298-310.

De Franco, R., Govers, R. and Wortel, R. (2007), Numerical Comparison of Different Convergent Plate Contacts: Subduction Channel and Subduction Fault, Geophysical Journal International 171, 435-450.

Demets, C., Gordon, R.G., Argus, D.F. and Stein, S. (1994), Effect of Recent Revisions to the Geomagnetic Reversal Time-Scale on Estimates of Current Plate Motions, Geophysical research letters 21, 2191-2194.

Dominguez, S., Lallemand, S.E., Malavieille, J. and von Huene, R. (1998), Upper Plate Deformation Associated with Seamount Subduction, Tectonophysics 293, 207-224.

Dominguez, S., Malavieille, J. and Lallemand, S.E. (2000), Deformation of Accretionary Wedges in Response to Seamount Subduction: Insights from Sandbox Experiments, Tectonics 19, 182-196.

Doubrovine, P.V. and TARduno, J.A. (2008), A Revised Kinematic Model for the Relative Motion between Pacific Oceanic Plates and North America since the Late Cretaceous, Journal of geophysical research 113, B12101, doi:10.1029/2008jb005585.

Espurt, N., Funiciello, F., Martinod, J., Guillaume, B., Regard, V., Faccenna, C. and Brusset, S. (2008), Flat Subduction
Dynamics and Deformation of the South American Plate: Insights from Analog Modeling, Tectonics 27, TC3011, doi: $10.1029 / 2007 \mathrm{tc} 002175$.

Ferrari, L., Valencia-Moreno, M. and Bryan, S., Magmatism and Tectonics of the Sierra Madre Occidental and Its Relation with the Evolution of the Western Margin of North America, In Geology of México: Celebrating the Centenary of the Geological Society of México: Geological Society of America Special Paper 422 (eds. S.A. Alaniz-Alvarez and A.F. Nieto-Samaniego) (2007) pp. 1-39.

Forsyth, D. and UyedA, S. (1975), Relative Importance of Driving Forces of Plate Motion, Geophysical Journal of the Royal Astronomical Society 43, 163-200.

Fuis, G.S., Moore, T.E., Plafker, G., Brocher, T.M., Fisher, M.A., Mooney, W.D., Nokleberg, W.J., Page, R.A., Beaudoin, B.C., Christensen, N.I., Levander, A.R., Lutter, W.J., Saltus, R.W. and Ruppert, N.A. (2008), Trans-Alaska Crustal Transect and Continental Evolution Involving Subduction Underplating and Synchronous Foreland Thrusting, Geology 36, 267-270.

Gorbatov, A. and Fukao, Y. (2005), Tomographic Search for Missing Link between the Ancient Farallon Subduction and the Present Cocos Subduction, Geophysical Journal International 160, 849-854.

Grevemeyer, I., Kaul, N., Diaz-Naveas, J.L., Villinger, H.W., Ranero, C.R. and Reichert, C. (2005), Heat Flow and BendingRelated Faulting at Subduction Trenches: Case Studies Offshore of Nicaragua and Central Chile, Earth and Planetary Science Letters 236, 238-248.

Gutscher, M.A., Malavieille, J., Lallemand, S. and Collot, J.Y. (1999a), Tectonic Segmentation of the North Andean Margin: Impact of the Carnegie Ridge Collision, Earth and Planetary Science Letters 168, 255-270.

Gutscher, M.A., Olivet, J.L., Aslanian, D., Eissen, J.P. and Maury, R. (1999b), The “Lost Inca Plateau': Cause of Flat Subduction beneath Peru?, Earth and Planetary Science Letters 335-341.

Gutscher, M.-A., Spakman, W., BijwaArd, H. and Engdahl, E.R. (2000a), Geodynamics of Flat Subduction: Seismicity and Tomographic Constraints from the Andean Margin, Tectonics 19.

Gutscher, M.A., Maury, R., Eissen, J.-P. and Bourdon, E. (2000b), Can Slab Melting Be Caused by Flat Subduction?, Geology 28, 535-538.

Gutscher, M.A., Spakman, W., BijwaArd, H. and Engdahl, E.R. (2000c), Geodynamics of Flat Subduction: Seismicity and Tomographic Constraints from the Andean Margin, Tectonics 19, 814-833.

Hayes, G.P., Wald, D.J. and Keranen, K. (2009), Advancing Techniques to Constrain the Geometry of the Seismic Rupture Plane on Subduction Interfaces a Priori: Higher-Order Functional Fits, Geochemistry Geophysics Geosystems 10, Q09006, doi:10.1029/2009gc002633.

Husker, A. and Davis, P.M. (2009), Tomography and Thermal State of the Cocos Plate Subduction beneath Mexico City, Journal of geophysical research 114, B04306, doi: 10.1029/2008JB006039.

JARRARD, R.D. (1986), Relations among Subduction Parameters, Reviews of Geophysics 24, 217-284.

Johnson, E.R., Wallace, P.J., Delgado Granados, H., Manea, V.C., Kent, A.J.R., Bindeman, I.N. and Donegan, C.S. (2009), Subduction-Related Volatile Recycling and Magma Generation 
beneath Central Mexico: Insights from Melt Inclusions, Oxygen Isotopes and Geodynamic Models, Journal of Petrology 50, 1729-1764.

KaRIG, D.E. (1978), Late Cenozoic Subduction and Continental Margin Truncation Along the Northern Middle America Trench, Geological Society of America Bulletin 89, 265-276.

KAY, S.M. and ABbruZZI, J.M. (1996), Magmatic Evidence for Neogene Lithospheric Evolution of the Central Andean "FlatSlab" between $30^{\circ} \mathrm{S}$ and $32^{\circ} \mathrm{S}$, Tectonophysics 259, 15-28.

Keppie, J.D. (2004), Terranes of Mexico Revisited: A 1.3 Billion Year Odyssey, International Geology Review 46, 765-794.

KeppIE, D.F., 2009. Subduction Erosion Processes with Application to Southern Mexico. PhD Thesis, McGill University, Montreal, $172 \mathrm{pp}$.

Keppie, J.D. and Moran-Zenteno, D.J. (2005), Tectonic Implications of Alternative Cenozoic Reconstructions for Southern Mexico and the Chortis Block, International Geology Review 47, 473-491.

Keppie, D.F., Currie, C.A. and Warren, C. (2009a), Subduction Erosion Modes: Comparing Finite Element Numerical Models with the Geological Record, Earth and Planetary Science Letters 287, 241-254.

Keppie, J.D., Moran-Zenteno, D.J., Martiny, B. and GonzalezTorres, E. (2009b), Synchronous 29-19 Ma Arc Hiatus, Exhumation and Subduction of Forearc in Southwestern Mexico, Geological Society, London, Special Publications 328, 169-179.

Kim, Y., Clayton, R.W. and Jackson, J.M. (2010), Geometry and Seismic Properties of the Subducting Cocos Plate in Central Mexico, Journal of geophysical research 115, B06310, doi: 10.1029/2009jb006942.

Klitgord, K.D. and Mammerickx, J. (1982), Northern East Pacific Rise-Magnetic Anomaly and Bathymetric Framework, Journal of geophysical research 87, 6725-6750.

Lallemand, S., Heuret, A. and Boutelier, D. (2005), On the Relationships between Slab Dip, Back-Arc Stress, Upper Plate Absolute Motion, and Crustal Nature in Subduction Zones, Geochemistry Geophysics Geosystems 6, Q09006, doi: 10.1029/2005GC000917.

Lonsdale, P. (2005), Creation of the Cocos and Nazca Plates by Fission of the Farallon Plate, Tectonophysics 404, 237-264.

Mammerickx, J. and Klitgord, K.D. (1982), Northern East Pacific Rise-Evolution from 25 My Bp to the Present, Journal of geophysical research 87, 6751-6759.

MANEA, V. and Gurnis, M. (2007), Subduction Zone Evolution and Low Viscosity Wedges and Channels, Earth and Planetary Science Letters 264, 22-45.

Manea, M., Manea, V.C., Ferrari, L., Kostoglodov, V. and BAndy, W.L. (2005), Tectonic Evolution of the Tehuantepec Ridge, Earth and Planetary Science Letters 238, 64-77.

Martinod, J., Funiciello, F., Faccenna, C., Labanieh, S. and Regard, V. (2005), Dynamical Effects of Subducting Ridges: Insights from 3-D Laboratory Models, Geophysical Journal International 163, 1137-1150.

Menard, H.W. (1978), Fragmentation of Farallon Plate by Pivoting Subduction, Journal of Geology 86, 99-110.

Moran-Zenteno, D., Cerca, M. and Keppie, J.D. (2007), The Cenozoic Tectonic and Magmatic Evolution of Southwestern Mexico; Advances and Problems of Interpretation, In Geology of México: Celebrating the Centenary of the Geological Society of México: Geological Society of America Special Paper 422 (eds. S.A. Alaniz-Alvarez and A.F. Nieto-Samaniego) pp. 71-91.
Moran-Zenteno, D., Corona-Chavez, P. and Tolson, G. (1996), Uplift and Subduction Erosion in Southwestern Mexico since the Oligocene: Pluton Geobarometry Constraints, Earth and Planetary Science Letters 141, 51-65.

Moran-Zenteno, D., Keppie, D.J., Martiny, B. and GonzálezTorres, E. (2009), Reassessment of the Paleogene Position of the Chortis Block Relative to Southern Mexico: Hierarchical Ranking of Data and Features, Revista Mexicana De Ciencias Geologicas 26, 177-188.

Müller, R.D., Sdrolias, M., Gaina, C. and Roest, W.R. (2008), Age, Spreading Rates, and Spreading Asymmetry of the World's Ocean Crust, Geochemistry Geophysics Geosystems 9, Q04006, doi: $10.1029 / 2007 \mathrm{gc001743.}$

Nieto-Samaniego, A.F., Alaniz-Alvarez, S.A., Silva-Romo, G., Eguiza-Castro, M.H. and Mendoza-Rosales, C.C. (2006), Latest Cretaceous to Miocene Deformation Events in the Eastern Sierra Madre Del Sur, Mexico, Inferred from the Geometry and Age of Major Structures, Geological Society of America Bulletin 118, 238-252.

O'Driscoll, L.J., Humphreys, E.D. and Saucier, F. (2009), Subduction Adjacent to Deep Continental Roots: Enhanced Negative Pressure in the Mantle Wedge, Mountain Building and Continental Motion, Earth and Planetary Science Letters 280, 61-70.

Ortega-Gutierrez, F., Solari, L.A., Ortega-Obregon, C., EliasHerrera, M., Martens, U., Moran-Ical, S., Chiquin, M., Keppie, J.D., De Leon, R.T. and SchaAf, P. (2007), The Maya-Chortis Boundary: A Tectonostratigraphic Approach, International Geology Review 49, 996-1024.

Ortega-Obregon, C., Solari, L.A., Keppie, J.D., Ortega-Gutierrez, F., Sole, J. and Moran-Ical, S. (2008), Middle-Late Ordovician Magmatism and Late Cretaceous Collision in the Southern Maya Block, Rabinal-Salama Area, Central Guatemala: Implications for North America-Caribbean Plate Tectonics, Geological Society of America Bulletin 120, 556-570.

Pardo, M. and SuÁRez, G. (1993), Steep Subduction Geometry of the Rivera Plate beneath the Jalisco Block in Western Mexico, Geophysical research letters 20, 2391-2394.

Pardo, M. and SuÁrez, G. (1995), Shape of the Subducted Rivera and Cocos Plates in Southern Mexico: Seismic and Tectonic Implications, Journal of geophysical research 100, 12357-12373.

Parsons, B. and Sclater, J.G. (1977), Analysis of Variation of Ocean-Floor Bathymetry and Heat-Flow with Age, Journal of geophysical research 82, 803-827.

Pérez-CAmpos, X., Kim, Y., Husker, A., Davis, P.M., Clayton, R.W., Iglesias, A., Pacheco, J.F., Singh, S.K., Manea, V.C. and GuRnis, M. (2008), Horizontal Subduction and Truncation of the Cocos Plate beneath Central Mexico, Geophysical research letters 35, L18303, doi:10.1029/2008g1035127.

Pilger, R.H. (1981), Plate Reconstructions, Aseismic Ridges, and Low-Angle Subduction beneath the Andes, Geological Society of America Bulletin 92, 448-456.

Pindell, J.L., Cande, S.C., Pitman Iit, W.C., Rowley, D.B., Dewey, J.F., Labrecque, J. and Haxby, W. (1988), A Plate-Kinematic Framework for Models of Caribbean Evolution, Tectonophysics 155, 121-138.

Protti, M., Guendel, F. and McNally, K. (1995), Correlation between the Age of the Subducting Cocos Plate and the Geometry of the Wadati-Benioff Zone under Nicaragua and Costa Rica, In Geologic and Tectonic Development of the Caribbean Plate Boundary in Southern Central America. Geological Society of America Special Paper 295 (ed' P. Mann) pp. 309-326. 
Rogers, R.D., Karason, H. and van der Hilst, R.D. (2002), Epeirogenic Uplift above a Detached Slab in Northern Central America, Geology 30, 1031-1034.

Ross, M.I. and Scotese, C.R. (1988), A Hierarchical Tectonic Model of the Gulf of Mexico and Caribbean Region, Tectonophysics $155,139-168$.

RufF, L.J. (1989), Do Trench Sediments Affect Great Earthquake Occurrence in Subduction Zones, Pure and Applied Geophysics 129, 263-282.

SAK, P.B., Fisher, D.M., Gardner, T.W., Marshall, J.S. and LaFemina, P.C. (2009), Rough Crust Subduction, Forearc Kinematics, and Quaternary Uplift Rates, Costa Rican Segment of the Middle American Trench, Geological Society of America Bulletin 121, 992-1012.

Schaaf, P., Moran-Zenteno, D., Hernandez-Bernal, M.D., SolisPichardo, G., Tolson, G. and Kohler, H. (1995), Paleogene Continental Margin Truncation in Southwestern Mexico: Geochronological Evidence, Tectonics 14, 1339-1350.

Singh, S.K. and PARdo, M. (1993), Geometry of the Benioff Zone and State of Stress in the Overriding Plate in Central Mexico, Geophysical research letters 20, 1483-1486.

Solari, L.A., de Leon, R.T., Pineda, G.H., Sole, J., Solis-Pichardo, G. and Hernandez-Trevino, T. (2007), Tectonic Significance of Cretaceous-Tertiary Magmatic and Structural Evolution of the Northern Margin of the Xolapa Complex, Tierra Colorada Area, Southern Mexico, Geological Society of America Bulletin 119, $1265-1279$.
Suárez, G., Escobedo, D., Bandy, W. and Pacheco, J.F. (1999), The 11 December, 1995 Earthquake $(M w=6.4)$ : Implications for the Present-Day Relative Motion on the Rivera-Cocos Plate Boundary, Geophysical research letters 26, 1957-1960.

Tovish, A., Schubert, G. and Luyendyk, B.P. (1978), Mantle Flow Pressure and the Angle of Subduction: Non-Newtonian Corner Flows, Journal of geophysical research 83, 5892-5898.

Turcotte, D.L. and Schubert, G., Geodynamics (Cambridge University Press, New York 2002).

Urrutia-Fucugauchi, J. and Flores-Ruiz, J. (1996), Bouguer Gravity Anomalies and Regional Crustal Structure in Central Mexico, International Geology Review 38, 176-194.

van Hunen, J., van den Berg, A.P. and Vlaar, N.J. (2002), On the Role of Subducting Oceanic Plateaus in the Development of Shallow Flat Subduction, Tectonophysics 352, 317-333.

van Hunen, J., van den Berg, A.P. and Vlaar, N.J. (2004), Various Mechanisms to Induce Present-Day Shallow Flat Subduction and Implications for the Younger Earth: A Numerical Parameter Study, Physics of The Earth and Planetary Interiors 146, 179-194.

von Huene, R. and Scholl, D.W. (1991), Observations at Convergent Margins Concerning Sediment Subduction, Subduction Erosion, and the Growth of Continental-Crust, Reviews of Geophysics 29, 279-316.

WatTs, A.B. and Ribe, N.M. (1984), On Geoid Heights and Flexure of the Lithosphere at Seamounts, Journal of geophysical research $89,1152-1170$.

(Received February 5, 2010, revised June 28, 2010, accepted August 18, 2010, Published online November 16, 2010) 